\title{
Does the Commonwealth Electoral Act Satisfy the Requirement That Representatives Be 'Directly Chosen' by the People?
}

\author{
Bede Harris $^{1}$ \\ ${ }^{1}$ School of Accounting and Finance, Charles Sturt University, Canberra, Australia \\ Correspondence: Bede Harris, School of Accounting and Finance, Charles Sturt University, Locked Bag 119, \\ Kingston, ACT 2604, Australia. E-mail: beharris@csu.edu.au
}

Received: March 29, 2016

Accepted: May 4, 2016 Online Published: May 29, 2016

doi:10.5539/jpl.v9n4p78

URL: http://dx.doi.org/10.5539/jpl.v9n4p78

\begin{abstract}
The electoral system embodied in the Commonwealth Electoral Act 1918 (Cth) is notable for its startling unfairness to voters who support minor parties. This article argues that the disparity between voter preferences and the allocation of seats in the House of Representatives means that the electoral system cannot be said to provide for the election of members 'directly chosen by the people', as required by s 24 of the Constitution, and is therefore open to challenge. Although challenges to the electoral system in Attorney General (Cth); Ex rel McKinlay v Commonwealth and McGinty v Western Australia were unsuccessful, dicta by majorities in both cases support the argument that at some point - albeit unstated by the courts in those cases - an electoral system will be so unrepresentative as not to be consistent with s 24. Subsequent decisions in Roach v Electoral Commissioner and Rowe $\mathrm{v}$ Electoral Commissioner, to the effect that franchise laws must be appropriate and adapted to the system of representative government, also provide grounds for a constitutional challenge to the current electoral system. The article ends with a discussion of the criteria to be used to determine what system would be consistent with direct representation of the people, and argues that the Single Transferrable Vote system satisfies the requirements of accurate reflection of voter sentiment and provision to voters of identifiable local representatives.
\end{abstract}

Keywords: Australia, constitution, Commonwealth, democracy, directly chosen, elections, electoral, franchise, government, implied right, proportionality, representative, vote

\section{Introduction}

The Australian electoral system embodied in the Commonwealth Electoral Act 1918 (Cth) is notable for the startling disparity it evinces between voter preferences and the allocation of seats in the House of Representatives. This is not surprising given that it is based on single-member electorates. Under such a system, the critical determinant of who is elected to the legislature is the location of electorate boundaries, not the overall popularity of parties among voters. A common feature of such systems is the dominance of two parties and the consequent freezing out of minor parties, which may be 'minor' only in the sense that they seldom obtain representation in the legislature, even if they have significant voter support. Most alarmingly, a single-member electorate system can lead to a party winning a majority of seats - and thus government - while winning a minority of votes nationwide.

Despite the manifest unfairness of the electoral system, it has been subject to constitutional challenge only twice - in Attorney General (Cth); Ex rel McKinlay v Commonwealth (1975) 135 CLR 1 and McGinty v Western Australia (1996) 186 CLR 40 (hereafter McGinty) - on both occasions unsuccessfully. Those challenges were based on the requirement contained in s 24 of the Constitution that members of the House of Representatives shall be 'directly chosen' by the people of the Commonwealth. More recent High Court decisions in Roach v Electoral Commissioner (2007) 233 CLR 162 and Rowe v Electoral Commissioner (2010) 243 CLR 1 (hereafter Rowe) have seen provisions contained in the Commonwealth Electoral Act 1918 (Cth) successfully challenged on the ground that they disproportionately limit an implied right to vote. The purpose of this article is to demonstrate how a challenge to the current electoral system using an argument based both on the requirement of direct election and on the doctrine of proportionality could succeed, and then to explore what type of electoral system would conform to the constitutional mandate that parliamentarians be 'directly chosen' by the people.

Part II of this article examines the extent to which the electoral system is unfair to voters by failing accurately to 
represent their views. Part III examines the reasoning of the High Court in McKinlay and McGinty. Part IV discusses how the High Court applied the concept of proportionality in the context of electoral law in Roach and Rowe to invalidate voting restrictions. Part V discusses how the proportionality test applied in Roach and Rowe could be used to challenge the constitutional validity of the current electoral system. Part VI discusses what the parameters of a constitutionally valid electoral system would be, taking into account the purposes served by elections in a system of representative government. This part also discusses how the Single Transferrable Vote system, used in the ACT and Tasmania, as well as in the Commonwealth Senate and in State upper houses, would be consistent with the Constitution and would provide fair representation for voters.

\section{The Nature of the Problem}

Democracy is a system, not a moral concept. Such moral value as attaches to it depends upon the extent to which it serves some norm which is external to it. According to political theory developed in Ancient Greece, that norm was the entitlement of citizens to participate in law-making. During the Enlightenment this came to be phrased in the language of rights - that each citizen was of equal status, from which flowed an equal right to participate in law-making, the only practical way of achieving that being through the mechanism of representative democracy. It was crucial to the success of vindication of that right that the franchise not be restricted by class or be distorted in its effect by, for example, weighting one person's vote differently from that of another, or by allocating law-making authority to legislative chambers representing social classes unequally.

Once one appreciates the concept of democracy as a mechanism used to give effect to a higher norm, two conclusions follow: First, democracy depends for its justification on a theory of individual rights, to which it is therefore subordinate. Second, whether an electoral system can be described as democratic is a question of degree, and depends on the extent to which that system gives effect to the right of citizens to equal influence over the law-making process. Thus the effectiveness of an electoral system in serving its purpose must be determined by how accurately it reflects the political sentiments of the voters, and an electoral system is less consistent with democracy the greater the extent that arbitrary factors distort that reflection.

If the purpose of an electoral system is therefore accurately to translate the political choices of voters into representation in the legislature, then the system embodied in the Commonwealth Electoral Act 1918 (Cth) fails spectacularly.

Inequity in representation is a well-known feature of single-member electorate voting systems. This is because it is the distribution of electorate boundaries, rather than the number of voters a party gets, which determines whether, and to what extent, parties obtain representation in the legislature. Put simply, a party whose supporters are widely dispersed across the country but which does not have majorities in particular electorates will fail to obtain representation. The single-member electorate system also leads to dominance of politics by two parties, and to the ineffectiveness of any votes cast for parties other than the dominant ones. This is true of all single-member electorate systems, whether the first past the post electoral system used in the United Kingdom, where all that is required to win a seat is a plurality (that is, more votes than any other party), or the preferential vote system used for elections for the House of Representatives, where a candidate must obtain an absolute majority to win a seat, and voters express preferences which are distributed until a candidate is successful. The preferential element does not make it any fairer for supporters of minor parties. Irrespective of who they really want to elect - that is, irrespective of to whom they give their first preference - the stark choice they face if they are voting for a minor party is either to stop expressing further preferences, in which case their vote has no effect on the outcome, (Note 1) or to express a preference between one of the two major parties who they may find equally unappealing but who they have to vote for if they want their vote to impact upon membership of Parliament.

The unfairness to voters for minor parties is illustrated by the following results, taken from elections held within the recent past: (Note 2) In 1990 the 11.4\% of first preference votes won by the Australian Democrats yielded not one seat for the party - yet by contrast, the Nationals won only $8.4 \%$ of first preference but $9.5 \%$ of the seats in the House of Representatives, simply because of where their voters lived relative to electoral boundaries. In 2004 and 2007 the Greens won over 7\% of the vote but achieved no representation in the House, and when they won their first and only seat in the House in 2010, that was after winning $11.7 \%$ of first preference votes nationwide. The result of this is that the major parties have won an astonishing $99.1 \%$ of all House of Representatives seats in the 26 elections held since 1949.

Even more disturbing for democratic legitimacy are the anomalies produced on a national scale. Take, for example, the following table which contains results from the elections held in 1990 and 1998: 


\begin{tabular}{llll}
\hline Year & Party & Nationwide \% of first preference votes & $\begin{array}{l}\text { \% of House of Representatives } \\
\text { seats }\end{array}$ \\
\hline 1990 & Labor & $39.4 \%$ & $52.7 \%$ \\
& Coalition & $43.4 \%$ & $46.7 \%$ \\
\hline 1998 & Labor & $40.1 \%$ & $45.2 \%$ \\
& Coalition & $39.1 \%$ & $54 \%$ \\
\hline
\end{tabular}

What is striking about these results is that clearly the 'wrong' party won both elections, in that the victor (that is, the party which obtained a majority in the House of Representatives) was less popular in terms of nationwide share of the vote than the vanquished. This is by no means a rare occurrence: Governments also came to power with fewer votes than were won by the opposition in 1954, 1961, 1969 and 1987.

Because it is the location, rather than the number, of voters that a party obtains that is critical to its electoral success, parties put most effort into campaigning and making promises in marginal seats - those where a small change in the number of votes won by a party will determine whether it wins the seat. Parties have no reason to expend energy campaigning vigorously in seats where they have a safe majority or, conversely, in which they have no hope of winning. Nationwide opinion polls published by the media are poor predictors of the outcome indeed, on many occasions they prove to be irrelevant, because a party can win a majority of first preference votes nation-wide and yet end up with a minority of seats in the House. What is really important is who the voters in the marginals will support. So, for example, while 12930814 votes were cast in the 2007 election, the outcome was effectively decided by 8772 voters in 11 electorates (Note 3) who, if they had given their first preferences to the Coalition instead of to Labor, would have handed victory to the former - and this in an election which, the allocation of seats in Parliament (83 to Labor and 65 to the Coalition) gave the appearance of a Labor landslide. In 2010 the margin was even closer - 13131667 votes were cast, but had just 2175 voters in two electorates (Note 4) voted for the Coalition instead of Labor (and had the Greens and Independents made the same decisions as to who to support in government), the Coalition would have won power. How can an electoral system be considered fair when the winning of government depends upon the geographical location of a tiny number of voters?

There has been much comment in recent years of how voters are becoming resentful of, and disengaged from, the political system. A reflection of this is the fact that an ever-increasing number of voters are expressing their frustration with the major parties by directing their support to parties other than Labor or the Coalition: In the 2007 election $14.5 \%$ of first preference votes went to minor parties or independents, (Note 5) but this increased to $18.2 \%$ in 2010 and to $21 \%$ in 2013 - and this is despite the fact that a first preference vote cast other than for one of the major parties amounts, in most instances, to no more than a gesture to be made before having to make a reluctant choice between parties that can actually win a seat.

\section{McKinlay and McGinty}

The unfairness inherent in the electoral system has led to two challenges reaching the High Court. In neither case was the court willing to accept arguments that electoral maldistribution was unconstitutional. Nevertheless, it is useful to examine the decisions in these cases, because even justices who were in the majority made statements which conceded that the Constitution does mandate some degree of voting equality.

In Attorney General (Cth); Ex rel McKinlay v Commonwealth (1975) 135 CLR 1 a challenge was launched against s 19 of the Commonwealth Electoral Act 1918 (Cth) which permitted a 10\% variation between the number of voters in an electorate. A majority of the court (Barwick CJ and McTiernan, Jacobs, Gibbs, Stephen and Mason JJ, with Murphy J dissenting) rejected the argument that where s 24 of the Constitution states that 'The House of Representatives shall be composed of members directly chosen by the people of the Commonwealth', this required equality of voting rights. Barwick CJ held (Note 6) that 'directly chosen' simply means that the election of MPs must be direct rather than indirect (for example, through an electoral college) and that it should be a popular election. He also cited the restricted nature of the franchise at the time of federation as an argument against the proposition that direct election meant equality of voting rights at the time the Constitution was drafted. (Note 7) McTiernan and Jacobs JJ reached same conclusion, rejecting the argument that the Constitution required 'absolute or as nearly as practicable absolute equality'. (Note 8) Importantly, however, their decision was based on a finding that the inequalities 'are not in any State so great that an election conducted in those divisions would not be a choosing of members by the people'. (Note 9) The significance of 
this will be explored later.

\section{Stephen J said (Note 10)}

It is, then, quite apparent that representative democracy is descriptive of a whole spectrum of political institutions, each differing in countless respects yet answering to that generic description. The spectrum has finite limits and in a particular instance there may be absent some quality which is regarded as so essential to representative democracy as to place that instance outside those limits altogether; but at no one point within the range of the spectrum does there exist any single requirement so essential as to be determinative of the existence of representative democracy

Mason J stated (Note 11) that

It is perhaps conceivable that variations in the numbers of electors or people in single member electorates could become so grossly disproportionate as to raise a question whether an election held on boundaries so drawn would produce a House of Representatives composed of members directly chosen by the people of the Commonwealth, but this is a matter quite removed from the proposition that s. 24 insists upon a practical equality of people or electors in single member electorates.

The only dissenter in McKinlay was Murphy J. He noted that whereas in 1900 franchise restrictions based on gender and property qualifications were seen as not inconsistent with the concept of direct choice by the people, the same would not be true in 1975. (Note 12) If, even despite this, s 24 was to be interpreted as imposing no mandate in relation to voting equality then it would mean that the Constitution (Note 13)

...would permit the most undemocratic deprivation or dilution of voting power, such as rotten boroughs, depriving women of a vote, and the imposing of property qualifications on voters. The State of New South Wales, intervening, adopted the stand that the Constitution would permit the members of the House of Representatives to be elected only by mayors and presidents of municipal and shire councils. It would mean also, as was argued, that a one member division could constitutionally contain twenty times the number of people or electors as another division in the same State and that one division could have twenty times the number of members as another division containing the same number of electors or people.

Murphy found that s 24 requires equality, based on democratic principle and, more tellingly, (Note 14) because of the

..absence of any other means of redress for those deprived of an equal share of representation, even where it is grossly unequal. The argument was advanced that no guarantee of electoral equality should be read into the Constitution because it was left exclusively to the Parliament to do what was fair. If Parliament failed, the remedy was with the people. The hollowness of this argument has been made apparent by the history of maldistribution in the United States and in Australia. If the legislature fails to ensure fairness, and there is no constitutional right enforceable in the courts, where is the remedy? ... History here and elsewhere reveals that with few exceptions, legislators who hold office because of an unbalanced electoral system will not act to change the system. The more unbalanced it becomes, the more severe are the consequences of correction and the more reluctant are the legislators to change it.

In McGinty v Western Australia (1996) 186 CLR 40 a challenge was brought against a state electoral system. Nevertheless it is relevant to a discussion of the Commonwealth electoral system because the flaws in the Western Australian electoral system are also manifested by that of the Commonwealth. The plaintiffs challenged provisions of the Electoral Distribution Act 1947 (WA) which provided that electorates in metropolitan Perth had an average of 23000 electors (plus or minus 15\%) while rural electorates had an average of 12000 electors (plus or minus $15 \%$ ). It is noteworthy that the phrase 'directly chosen by the people' in s 73(2)(c) is the same requirement as appears in s 24 of the Commonwealth Constitution.

The challenge in McGinty differed from that in McKinlay in that it was launched in the wake of the finding by the High Court in Australian Capital Television v Commonwealth (No. 2) (1992) 177 CLR 106 that the doctrine of representative government is implicit in the Commonwealth Constitution (and thus also in the Constitution of Western Australia because it embodies the same system of government). Thus the appeal in McGinty was based on the argument that that doctrine, and not just the phrase 'directly elected by the people', mandated voting equality. The court (Brennan CJ, Dawson, McHugh and Gummow JJ, with Toohey and Gaudron JJ dissenting) dismissed the challenge.

Among the majority, Dawson J rejected the argument that representative government requires equality of voting, concluding that the Constitution did not imply any particular electoral system, of which there are many, each 
with relative advantages and disadvantages. (Note 15) He did however concede that in McKinlay McTiernan and Jacobs and Mason $\mathrm{J}$ had said that at some point electoral inequality might be inconsistent with a choice by the people, holding (Note 16)

In my view, both McTiernan and Jacobs JJ and Mason $\mathrm{J}$ had in mind extreme situations markedly different from that which exists under the relevant Western Australian legislation.

This is a recognition that representation contains some element of equality - in other words, that it is a matter of degree. The questions begged, but not answered, by this statement was how 'extreme' an electoral system would have to be before it was inconsistent with a choice by the people, and what criteria should be used to answer that question.

Similarly, Gummow J held that no particular voting system is required by the Constitution (Note 17) and that all that was required (Note 18) was

...ultimate control by the people, exercised by representatives who are elected periodically.

However, he did accept that variations in voter numbers between electorates 'could be so disproportionate as to deny ultimate control by popular election' (Note 19) and that the Constitution required universal adult suffrage 'which could not be abrogated by reversion to the system which operated in one or more colonies at the time of federation'.

Toohey $\mathrm{J}$, in dissent, said that democracy is a dynamic phenomenon and that the Constitution must be construed as a living force and should be interpreted taking into account political, social and economic developments since 1900 , not as if it was frozen at that date, (Note 20) so while 'the essential feature of representative democracy is government by the people through their representatives', what is required by representative democracy will change over time, and the franchise as it existed in 1900 would now be seen as falling short of what is required by representative democracy. (Note 21) He noted that the 1986 Constitutional Commission (Note 22) said that

..one vote one value is an essential principle of democracy. It is fundamental to a sense of meaningful participation in Australia's democratic polity.

He further held that while it is true that people can disagree on what limits would or would not satisfy the requirements of representative democracy, that did not detract from the fact that the courts had to discharge their constitutional role in determining whether the electoral system was compatible with the doctrine of representative government. On this basis he held that the malapportionment under the Western Australian legislation was incompatible with doctrine of representative democracy. (Note 23) Similar statements were made by Gaudron $\mathrm{J}$ in her dissenting judgment, saying that one could contemplate electoral laws which were inconsistent with s 24 - for example, a law excluding women or members of a racial minority from the franchise or subjecting the franchise to a property requirement. (Note 24) Said that the concept of choice by the people evolved over time and depended on the development of democratic standards, (Note 25) so what might have been permitted under s 24 at one time might not be permitted at another. On this basis she held that the malapportionment in Western Australia was not reasonably appropriate and adapted to effective parliamentary representation in light of current democratic standards.

The result of this is that four of the six members of the court accepted that at some point, an electoral system could be so disproportionate as to not comply with the constitutional requirement of direct representation of the people - what was lacking was the judges' enunciation of a test, or threshold, to determine where that point was.

\section{The Proportionality Test in Roach and Rowe}

The two most recent cases in which the constitutionality of electoral laws was challenged differed from McKinlay and McGinty in that they were decided by applying the proportionality test developed by the High Court in the implied freedom of political communication cases. (Note 26)

In Roach v Electoral Commissioner (2007) 233 CLR 162, the High Court considered a challenge to amendments to the Commonwealth Electoral Act 1918 (Cth) which replaced a provision denying the franchise to anyone serving a period of imprisonment of longer than three years with one denying the franchise to anyone serving any term of imprisonment. A majority of the court (Gleeson CJ, Gummow, Kirby and Crennan JJ, with French, Hayne and Heydon JJ dissenting) held the amendment invalid on the ground that it infringed the right to vote which is derived from ss 7, 24 and 128 of the Constitution in that by failing to discriminate between long and short-term sentences, Parliament had disproportionately limited that right.

Gleeson CJ held (Note 27) that because of changes in historical circumstances, it is now understood that whereas at the time of federation there was no acknowledged right to universal suffrage, matters were now different and 
the Constitution contained an implied right to vote:

Could Parliament now legislate to remove universal adult suffrage? If the answer to that question is in the negative (as I believe it to be) then the reason must be in the terms of ss 7 and 24 of the Constitution, which require that the senators and members of the House of Representatives be "directly chosen by the people" of the State or the Commonwealth respectively. In 1901, those words did not mandate universal adult suffrage...In McKinlay McTiernan and Jacobs JJ said that "the long established universal adult suffrage may now be recognized as a fact". I take "fact" to refer to an historical development of constitutional significance... As Gummow J said in McGinty $v$ Western Australia, we have reached a stage in the evolution of representative government which produces that consequence. I see no reason to deny that, in this respect, and to this extent, the words of ss 7 and 24, because of changed historical circumstances including legislative history, have come to be a constitutional protection of the right to vote. That, however, leaves open for debate the nature and extent of the exceptions. The Constitution leaves it to Parliament to define those exceptions, but its power to do so is not unconstrained....It is difficult to accept that Parliament could now disenfranchise people on the ground of adherence to a particular religion.....It is easy to multiply examples of possible forms of disenfranchisement that would be identified readily as inconsistent with choice by the people, but other possible examples might be more doubtful. An arbitrary exception would be inconsistent with choice by the people.

He concluded that whereas disenfranchisement based on the duration of a sentence would constitute a rational limitation on the franchise (as duration is, however imperfectly, related to the seriousness of the offence), denial of the franchise following upon imprisonment irrespective of duration (Note 28)

...broke the rational connection necessary to reconcile the disenfranchisement with the constitutional imperative of choice by the people

and was thus invalid.

Gummow, Kirby and Crennan JJ began by observing that in McGinty members of the court had acknowledged that representative democracy is a dynamic, rather than static, institution (Note 29). The question therefore was to what extent the legislative capacity conferred on Parliament to legislate with regard to the franchise was restricted by the requirements of representative government, (Note 30) which was to be determined by asking whether a restriction on the franchise was (Note 31)

...reasonably appropriate and adapted to serve an end which is consistent or compatible with the maintenance of the constitutionally prescribed system of representative government.

which, the Justices noted, was otherwise known as the proportionality test. In the present case, the Justices concluded that the disenfranchisement of all persons given a sentence of imprisonment, irrespective of duration of sentence, went beyond what was reasonably appropriate and adapted to the maintenance of representative government, and was therefore invalid. (Note 32)

In Rowe v Electoral Commissioner, (2010) 234 CLR 1 a majority of the court (French CJ, Gummow, Bell and Crennan JJ; with Hayne, Heydon and Kiefel JJ dissenting) upheld a challenge to amendments to the Commonwealth Electoral Act 1918 (Cth) which shortened the time within which voters could enrol after an election had been called in order to be able to vote at that election. Under the amendments a new voter had only until $8 \mathrm{pm}$ on the same day that the writs for the election were issued to register as a voter, and registered voters had only three days after the writs were issued to transfer their enrolment to a different electorate. Previously, new voters had had seven days from the issue of the writs to enrol as voters or amend their enrolment.

French CJ began (Note 33) by stating that the mandate in s 24 of the Constitution is that members of Parliament shall be 'directly chosen by the people and that a franchise law can be justified only if

...it serves the purpose of the constitutional mandate. If the law's adverse legal or practical effect upon the exercise of the entitlement to vote is disproportionate to its advancement of the constitutional mandate, then it may be antagonistic to that mandate. If that be so, it will be invalid.

He acknowledged that changed historical circumstances since federation meant that now 'directly chosen by the people' required universal adult franchise, (Note 34) and cited with approval findings by members of the court in Roach to the effect that restrictions on universal adult franchise had to be justified by a 'substantial reason'. (Note 35) Where a change in the law causes a detriment to a person's opportunity to vote then (Note 36)

Its justification must be that it is nevertheless, on balance, beneficial because it contributes to the fulfilment of the mandate. If the detriment, in legal effect or practical operation, is disproportionate to 
that benefit, then the law will be invalid as inconsistent with that mandate, for its net effect will be antagonistic to it. Applying the terminology adopted in Roach, such a law would lack a substantial reason for the detriment it inflicts upon the exercise of the franchise. It is therefore not sufficient for the validity of such a law that an election conducted under its provisions nevertheless results in members of Parliament being "directly chosen by the people".

The question was whether the change to the enrolment period survived the proportionality test. After reviewing the Commonwealth's arguments that the changes in the law were directed towards allowing the Australian Electoral Commission to discharge its duties more efficiently, French CJ concluded that (Note 37)

..the heavy price imposed by the Amendment Act in terms of its immediate practical impact upon the fulfilment of the constitutional mandate was disproportionate to the benefits of a smoother and more efficient electoral system to which the amendments were directed.

Gummow and Bell JJ noted dicta from previous cases in which it had been asserted that historical developments had resulted in an acceptance that the words 'directly chosen by the people' meant universal adult suffrage. (Note 38) They also cited with approval (Note 39) a dictum by Isaacs J in Keane v Kirby (1920) 27 CLR 449 at 459, that

the ballot itself is only a means to an end, and not the end itself... and the end aimed at is the free election of a representative by a majority of those entitled to vote.

They concluded (Note 40) that

...the legislative selection of the ballot system of voting and provisions for the efficacy of that system is not an end in itself but the means to the end of making elections as expressive of the will of the majority of the community as proper practical considerations permit. It is that understanding which explains the force of the phrase "directly chosen by the people" in ss 7 and 24 of the Constitution.

Gummow and Bell JJ found that the legislative changes had had the practical effect of disenfranchising people who would otherwise have been entitled to enrol, and that the reasons put forward by the Commonwealth justifying the changes were substantial in the sense that they satisfied the proportionality test used in Roach. (Note 41) They concluded by rejecting the argument by the Commonwealth that the changes were necessary in order to avoid electoral fraud, noting that there was no evidence of systemic fraud necessitating the changes. On this basis they found that the amendments went beyond what was justified by the Constitution. (Note 42)

Crennan J (Note 43) adopted statements from Roach by Gleeson CJ to the effect that constitutional evolution means that 'chosen by the people' requires universal adult suffrage, and by Gummow, Kirby and Crennan JJ (Note 44) to the effect that although the concept of representative democracy

..is a category of indeterminate reference, where the scope for judgment may include matters of legislative and political choice...that does not deny the existence of a constitutional bedrock when what is at stake is legislative disqualification of some citizens from exercise of the franchise.

She found (Note 45) that on the evidence presented, the respondent had not demonstrated that the challenged provisions had been enacted for a reason substantial enough to justify the disenfranchisement of voters and this were not consistent with the concept of direct choice by the people. (Note 46)

\section{Using the Previous Decisions as the Basis of a Challenge to the Electoral System}

In light of the above cases, what can be said about the power of Parliament to legislate in relation to the franchise? To what extent could previously decided cases support a challenge to the fairness of electoral system arising out of the flaws identified in Part II of this article?

Although majorities in both McKinlay and McGinty rejected the argument that the phrase 'directly chosen by the people' in s 24 of the Constitution mandated equality of voters as between electorates, sufficient justices to comprise a majority of the court held that, at some point, an electoral system could become so unequal as to infringe the s 24 requirement of direct choice by the people. (Note 47). This is of critical importance, because it constituted a recognition that, notwithstanding the majority's averments that s 24 did not require numerical equality of voters in electorates, the phrase 'directly chosen by the people' did indeed set some standard with which franchise laws must comply. By making this concession, the majorities in these cases were acknowledging that there is a qualitative element to the concept of a direct choice of the people. This in turn means what constitutes democracy cannot be left to the mercy of Parliament - and that it is necessary to posit a constitutional test of what democracy means.

Given that a majority of the court agreed that a franchise law could be so undemocratic as to go beyond the 
requirements of a direct choice of the people, it was, with respect, incumbent on the court to determine what those requirements were and to explain why a law permitting disparities between electorates was consistent with those requirements. Instead the court said that there was a line - somewhere - beyond which Parliament could not go, but that the laws permitting disparities as between electorates did not cross that line. Yet the court did not explain why this was, other than to say that compliance with the requirements of democracy was a matter of degree. With respect, that is obvious. Cases of this nature cannot be decided other than by the courts articulating a test which stipulates what the fundamental requirements of democracy are and then evaluating the extent to which electoral systems are consistent with that test - and this the courts in McKinlay and McGinty failed to do.

The majorities in Roach and Rowe adopted a much broader approach than that used in McKinlay and McGinty. In both cases majorities of the court adopted an ambulatory approach to the phrase 'directly chosen by the people', holding that because of historical developments in the understanding of Australian democracy, the phrase must be taken as to imply a constitutional requirement of universal adult suffrage, something that the court had not gone so far as to say in the earlier cases. Furthermore, by using the proportionality test to determine the constitutionality of limitations on the right to vote, the majorities in Roach and Rowe broadened the circumstances in which a law might be found to be incompatible with the Constitution. The test formulated in Roach was whether a franchise law is (Note 48)

...reasonably appropriate and adapted to serve an end which is consistent or compatible with the maintenance of the constitutionally prescribed system of representative government.

In Rowe the test was phrased as requiring an analysis of the extent to which a law was proportionate to the constitutional requirement of direct choice by the people. (Note 49)

The question which must now be addressed is: Given that the data presented in Part I of this article indicates that the operation of the voting system contained in the Commonwealth Electoral Act 1918 (Cth) leads to election results which are severely distorted in that the true choice of voters is not reflected in the election results, and given that the courts have accepted the principle that disproportionality can lead to unconstitutionality, are there now grounds for challenging the validity of that system? Surely use of the very term 'proportionality' in the constitutional context begs the question as to the constitutionality of an electoral system which produces such disproportionate results? The system embodied in our current electoral law which allows a party to win power with a minority of votes (to mention just one flaw manifested by the system) is clearly not a law which is proportionate or, to use the phraseology adopted by the High Court, is not appropriate and adapted to the requirements of representative government, chief among which must surely be accurate reflection of the will of the people.

This issue is of course important in any democracy, but it assumes particular significance in a constitutional system, such as that of Australia, which lacks a comprehensive Bill of Rights. (Note 50). This was noted in academic commentary in 1902 on the then new Constitution by Moore who wrote that 'the prevalence of the democratic principle' was the 'predominant feature' of the Constitution and that the 'great underlying principle is, that the rights of individuals are sufficiently secured by ensuring, as far as possible, to each a share, and an equal share, in political power'. (Note 51) This formed part of the reasoning by Mason CJ in Australian Capital Television v Commonwealth (No.2), who emphasised the critical role of parliamentary representation in the constitutional scheme. (Note 52). This was recently re-affirmed in the judgment of Gageler J in McCloy v New South Wales [2015] HCA 34, who stated (Note 53) that Moore's 'great underlying principle'

...underlines an important aspect of the manner in which the system of representative and responsible government established by Chs I and II of the Constitution is dependent on the choice made by electors. Electoral choice is the means of constituting the Parliament of the Commonwealth, and of indirectly constituting the Executive Government of the Commonwealth.

An electoral system which produces results which so obviously distorts the views of voters cannot be said to be consistent with this 'great underlying principle'. Surprisingly, however, despite the centrality of democracy to the Constitution, no challenge has been launched against the system since McKinlay and McGinty, and none of the academic commentary on the meaning of the words 'directly chosen by the people' has addressed the question of whether the gross disproportionality of the system has any constitutional implications. (Note 54)

\section{Setting the Parameters of a Constitutionally-Valid Electoral System in Accordance with Its Constitutional Purpose}

Assuming that a challenge was launched against our current electoral system, how would a court determine what the essential characteristics of representative government and / or direct choice by the people are? Or, to phrase 
the question in terms of the proportionality test, what criteria are so fundamental to democracy that a departure from them would mean that the system was no longer appropriate and adapted to the maintenance of representative government? If such a challenge was launched, the courts would be called upon to distinguish between those systems which are consistent with the achievement of the objectives of democracy and those which are not.

In Rowe, French CJ held that a franchise law can be justified only if (Note 55)

...it serves the purpose of the constitutional mandate. If the law's adverse legal or practical effect upon the exercise of the entitlement to vote is disproportionate to its advancement of the constitutional mandate, then it may be antagonistic to that mandate. If that be so, it will be invalid.

Thus, what is called for is a teleological evaluation of the electoral system - that is, an electoral system is constitutionally valid only to the extent that it serves its underlying purpose or purposes of representative democracy. What then are those purposes?

In its original direct form in Ancient Greece, democracy was 'rule by the people' in the truest sense of that term, because all citizens were members of the assembly, and this obviously meant that the law-making body reflected the diversity of views among citizens with complete accuracy. (Note 56) It follows that in a representative democracy, where the citizen is not directly involved in law-making, and thus relies on an electoral system to ensure that his or her views are represented by those who are members of the legislative body, conformity to the principle of rule by the people requires that the electoral system should operate in such a way as to reflect, with as little distortion as possible, the same diversity of views as would be reflected in a system of direct democracy. The data provided in Part II of this article demonstrates that our current electoral system so obviously fails to do this.

If accurate reflection of the will of the voters was the sole purpose of the system of representative democracy, then legislative compliance with that constitutional mandate would be relatively easy, and could be achieved by means of a system of pure proportional representation, where candidates are elected from party lists and each party receives seats in proportion to the number of votes it obtained nationwide. (Note 57) However representative democracy, in the particular form it which it developed in the United Kingdom and subsequently in Australia, serves an additional purpose, which is to provide voters with identifiable representatives to whom they can take their concerns. A system of pure proportional representation would not serve that purpose, as under such a system the country is effectively one large electorate, with MPs representing no particular locality.

We can then say that under a system of representative government, the electoral system serves two purposes, and that these purposes, while both important, are in tension. Furthermore, an electoral system which best serves one purpose will fail in relation to the other: Pure proportional representation, which best reflects the popular will, fails to provide identifiable representatives to electors because it is the placing of candidates on lists by political parties, rather than selection by the voters, which determines who is elected to all or some of the seats. In other words, the voters have no choice in relation to the identity of the legislators representing them, and so for that reason, their choice is not 'direct'. By contrast, the single-member electorate system we currently have, fails to reflect voter sentiment, but does provide voters with identifiable local representatives.

Thus the phrase 'directly elected' requires that the electoral system serve both purposes. Taking a literal approach to ss 7 and 24, while the Macquarie Dictionary does not define 'directly', it defines 'direct' as meaning 'without intervening agency; immediate; personal'. (Note 58) Yet if the electoral system produces a distorted view of the sentiments of the voters, does that not mean that because of the way it operates, the intervening agency of the electoral itself prevents the achievement of 'directness' in the sense of direct reflection of the will of the voters? I would argue that the answer to this is in the affirmative, and that because the current system operates in such a way as to not accurately reflect the political sentiment of voters, and compromises their choice by in most seats denying votes any effect unless they are used to express a preference for one of the two major blocs, it does not result in a House of Representatives that is 'directly chosen' by the people. Instead, the choice is intermediated by a system which in many cases will require voters to choose a candidate who they prefer only indirectly in the sense that they vote for the candidate who (in the case of voters who would support a minor party) is the least worse among two alternatives they do not want.

From this one can conclude that consistency with the concept of direct choice of the voters means that the electoral system must balance the competing criteria identified above: accurate representation of the political sentiments of the overall population, and the provision of an identifiable representative to voters. This means that the electoral system must be designed in such a way as to achieve a reasonable compromise between each. To use the language of the High Court, an electoral law needs to be drafted in such a way as to achieve 
proportionality between the two criteria. This in turn would satisfy the overall constitutional requirement that the electoral law be appropriate and adapted to a system of representative government based on direct representation of the voters. If the Commonwealth Electoral Act 1918 (Cth) was successfully challenged on the ground that the distortions it produces render it inconsistent with the requirement for direct election contained in ss 7 and 24 , a decision by the High Court in those terms would need to set parameters of sufficient clarity within which Parliament could operate when fashioning a new electoral system.

In doing so, Parliament would not need to look far - the multi-member electorate Single Transferrable Vote (STV) system, already used in the legislative houses that provide government in the ACT and Tasmania, as well as in the Senate and all State upper houses, barring Tasmania, (Note 59) satisfies the objectives of proportionality and the provision of identifiable representatives to voters. The system is also used in the houses that form government in the Republic of Ireland and Malta.

Under STV, the jurisdiction is divided into a number of large electorates, each returning more than one member. Parties may nominate as many candidates for each electorate as there are seats to be filled. Voters receive a ballot paper on which all the parties' candidates are listed, and indicate their preferences. The number of votes required for a candidate to be elected (referred to as the 'threshold') is one vote plus the number of votes cast in the electorate, divided by the number of seats plus one. If a candidate reaches the threshold after the first count of votes, he or she is declared elected. Any votes a candidate receives in excess of what they required to be elected are redistributed among the remaining candidates - the calculation is complex, but the objective is to ensure that if, for example, candidate A needed 14000 votes to be elected and obtained 15000 votes, the 1000 surplus votes are distributed among the remaining candidates in the same proportions that all voters for candidate A indicated their preferences. The process of distributing preferences goes on in successive rounds of counting. If no remaining candidate reaches the threshold after redistribution of the preferences of the most recently elected candidate, the candidate who received the fewest votes in that round of counting is eliminated and his or her second preferences are transferred to the remaining candidates. The process continues until all seats in the electorate are filled. There is range of STV systems, differing in the way in which votes are transferred, but all have in common the feature of multi-member electorates and transferrable preferences. The advantage of STV is that as well as leading to highly proportionate results, (Note 60) all members of the legislature are identifiable with a specific electorate, and that unlike in systems which rely on party lists, voters rather than parties have ultimate control over whether each candidate is elected.

If STV was adopted, the most important issue to determine would be the number of members returned by each multi-member electorate. The critical factor here is that the greater the number of MPs returned by each electorate, the more proportional the outcome of elections, and the less likelihood there is that a government can be elected without securing a majority of votes nationwide. (Note 61) As we have seen in Part II of this article, that is a scandalous, but by no means rare, occurrence under our current single-member electoral system. By contrast, in Ireland (Note 62) this has occurred twice (Note 63) in the 18 elections held since the introduction of the system, which uses a mix of three, four and five member electorates. In Malta, which uses five-seat electorates, it has occurred six times (Note 64) in 23 elections. (Note 65) The case of Tasmania (Note 66) is particularly interesting, because it had seven-seat electorates between 1959 and 1986, during which period eight elections were held and no government won power with less than a majority of votes. From 1989 the number of seats per electorate was reduced to five, and in the eight elections held since them, governments were twice (Note 67) been able to win power with a minority of votes. The implications of this are discussed later.

Another important factor to consider is how the number of seats per electorate affects the threshold for election: In a five-member electorate, the threshold is $16.7 \%$ of the vote plus 1 . Thus a party that had, for example, $15 \%$ support nationwide, but no sufficient concentration of voters in any particular electorate, would not obtain representation in Parliament. In a seven-member electorate, the threshold is $12.5 \%+1$ vote. If there were nine-member electorates, the threshold would be $10 \%+1$ vote. (Note 68 ).

The critical question here is how to balance the representivity of the system against the degree of contact voters have with their representatives. Where would the line be between an electoral system which satisfied the constitutional requirement of proportionality and one which did not? What would Parliament need to do to ensure that even legislation embodying the STV system would survive constitutional challenge? Is the selection of five, seven or nine-member electorates (or indeed electorates returning any other number of members) inevitably arbitrary? I would argue that a way out of this conundrum is to focus on the issue raised at the start of this article - namely that a key defect in the current electoral system is the fact that it not infrequently produces such disproportionality between votes and seats as to enable a party with a minority of votes nationwide to win an election or, to put it positively, a basic test of the fairness of the electoral system is that it should lead to 
government by parties which in combination have the support of at least $50 \%$ of the voters. It follows that a reasonable standard to set for a new electoral system would be that it should provide for whatever minimum number of seats per electorate will reduce, as far as possible, the likelihood of a government without majority support winning power. Choosing the minimum number of seats needed to achieve that objective will ensure that voter contact with representatives is maximised, and the geographical size of seats is minimised. The question is: Where does the mathematical cut-off point in the number of seats per electorate lie in order to eliminate this problem?

Here the experiences of Ireland and Tasmania, both of which use five-member electorates, are instructive: As discussed above, governments have won power with a minority of seats two of 18 (that is $11.1 \%$ ) of elections in Ireland, and in six out of 23 elections $(26 \%)$ in Malta. In Tasmania the experience was similar: During the period since that jurisdiction a reduced the number of seats per electorate from seven to five, governments won power with a minority of votes in two out of eight $(25 \%)$ of elections. These results indicate that a system based on five-member electorates still carries a significant risk that a government can win power with a minority of votes. Most revealingly, however, is the fact that in the period 1959-86 in Tasmania, when there were seven-member electorates, and eight elections were held, no government won power with a minority of votes. This then leads one to conclude that adopting a seven-member per electorate system would virtually eliminate the possibility of a government winning a majority of seats with a minority of votes, without making electorates larger than they need to be to achieve that objective, and so this is the threshold at which I would argue that the line should be drawn between an electoral system which accorded with the constitutional mandate of direct representation of the people and one which did not.

One final matter must be mentioned: Section 24 of the Constitution requires that members be assigned to States in proportion to their populations and also requires that each original State be allocated a minimum of five members. Section 29 of the Constitution prohibits electoral boundaries from crossing State boundaries. Assuming a seven-member per electorate system was adopted, sections 24 and 29 would require that Tasmania, as the State with the smallest in population, would have a single electorate returning seven members. Taking that allocation as the starting point, the distribution of seats in the House of Representatives, based on 2015 population figures, would be as follows:

$\begin{array}{ll}\text { New South Wales } & 103 \\ \text { Victoria } & 80 \\ \text { Queensland } & 64 \\ \text { Western Australia } & 35 \\ \text { South Australia } & 23 \\ \text { Tasmania } & 7 \\ \text { ACT } & 5 \\ \text { NT } & 3 \\ \text { TOTAL: } & 320\end{array}$

An increase in the number of members of the House of Representatives would no doubt be controversial in an era when politicians are subject to increasing mistrust and where there is corresponding disillusionment with, and disengagement from, the political system. Yet it would be paradoxical if the public were to oppose such an expansion, given that it would result in an overwhelmingly fairer electoral system, the political consequences of which would likely include the breaking of the Coalition-Labor duopoly over government which is the source of much of that dissatisfaction. Furthermore, when compared to other democracies, Australian voters are under-represented at federal level: At the time of the 2013 federal elections, there were on average 92351 voters in reach of the House of Representatives' 150 seats. This compares to 71423 registered voters per seat in the United Kingdom in 2015, and 25953 voters per seat in New Zealand in 2014. Increasing the number of seats in the House of Representatives to 320 would decrease the number of voters to representatives to 43289 , which would clearly not be out of step with democratic norms.

\section{Conclusion}

If the High Court was to make a decision in the terms argued for in this article, it would no doubt be criticised as engaging in judicial activism - yet, as the analysis of precedent in this article demonstrated, such a decision would build upon, and be consistent with, existing doctrine. The fundamental question to be considered is this: Can the current electoral system, with the manifestly unfair results it produces, be considered to satisfy the 
constitutional requirements of representative government and the over-arching purpose of an electoral system in a democracy? I would argue that the answer to that question is in the negative, and that for that reason, the validity of the electoral system is open to challenge Furthermore I would argue that, in evaluating the constitutionality of any alternative electoral system, the courts should engage in a teleological inquiry and determine the extent to which such a system serves the principle of representivity - the key criterion to be satisfied being that the attainment of government must be achievable only through winning an overall majority of the national vote. The data shows that an STV system using seven-seat electorates satisfies that requirement.

\section{References}

Australian Electoral Commission. (n.d.). Retrieved from http://www.aec.gov.au

Catt, H., Harris, P., \& Roberts, N. (1992). Voter's Choice: Electoral Change in New Zealand? Wellington: Dunmore Press.

Commonwealth of Australia, Constitutional Commission, Final Report of the Constitutional Commission. (1988). Canberra: AGPS.

Farrell, D. (1997). Electoral Systems, A Comparative Introduction. New York: Prentice Hall. http://dx.doi.org/10.1007/978-1-349-15009-0

Farrell, D., \& McAllister, I. (2004). Voter Satisfaction and Electoral Systems: Does Preferential Voting in Candidate-Centred Systems make a Difference? Irvine: Center for the Study of Democracy). Retrieved from http://www.escholarship.org/uc/item/4c51z9mt?display=all\#page-10

Gray, A. (2007). The Guaranteed Right to Vote in Australia. 7 Queensland University of Technology Law and Justice Journal, 178. http://dx.doi.org/10.5204/qutlr.v7i2.131

Hansen, M. (1991). The Athenian Democracy in the Age of Demosthenes. Cambridge, Mass.: Blackwell.

Lakoff, S. (1996). Democracy: History, Theory, Practice. Boulder: Westview Press.

Macquarie Dictionary $6^{\text {th }}$ ed. (2013). Pan Macmillan Australia: Tuggerah.

Mercurio, B., \& Williams, G. (2004). Australian Electoral Law: 'Free and Fair'? 32 Federal Law Review, 365.

Moore, W. H. (1902). The Constitution of the Commonwealth of Australia. London: John Murray.

Parliament of Tasmania, House of Assembly Election Results 1909-2014. (3 April 2014). Retrieved from http://www.parliament.tas.gov.au/tpl/Elections/ahares.htm

Republic of Ireland, Department of Environment, Community and Local Government. Retrieved from http://www.environ.ie/en/LocalGovernment/Voting/

Tasmanian Electoral Commission. (2015). Retrieved from http://www.tec.tas.gov.au/

The Electoral Knowledge Network. (2016). Electoral Systems. Retrieved from http://aceproject.org/ace-en/topics/es/esd/esd02/default

Twomey, A. (2000). The Federal Constitutional Right to Vote in Australia. 28 Federal Law Review, 125.

University of Malta. (2013). A Collection of electoral data for the Maltese islands. Retrieved from http://www.um.edu.mt/projects/maltaelections/elections/parliamentary

Whyte, W. (2007, June 3). Dail Elections. Retrieved from http://www.ark.ac.uk/elections/gdala.htm

Williams, G. (1996). Sounding the Core of Representative Democracy: Implied Freedoms and Electoral Reform. 20 Melbourne University Law Review, 828.

\section{Notes}

Note 1. Indeed under s 268(1) of the Commonwealth Electoral Act 1918 (Cth) a ballot paper on which all preferences are not filled in is ruled informal - in other words, invalid.

Note 2. All results are taken from the Australian Electoral Commission website at http://www.aec.gov.au

Note 3. These electorates were: Bass, Bennelong, Braddon, Corangamite, Cowan, Deakin, Flynn, Hasluck, Roberston, Swan and Solomon.

Note 4. The electorates of LaTrobe and McEwen. 
Note 5. That is to parties other than the Liberals, Labor and the various manifestations of the Nationals (Liberal Nationals, Nationals and Country Liberals). The calculation ignores informal votes.

Note 6. McKinlay at 21.

Note 7. Ibid 19-21, 25, 33.

Note 8. Ibid 36-7.

Note 9. Ibid 39.

Note 10. Ibid 57.

Note 11. Ibid 61.

Note 12. Ibid 69.

Note 13. Ibid 71.

Note. 14 Ibid 71-2.

Note 15. Mc Ginty at 184.

Note 16. Ibid 189.

Note 17. Ibid 284-5.

Note 18. Ibid 285.

Note 19. Ibid 286.

Note 20. Ibid 200.

Note 21. Ibid 201.

Note 22. Commonwealth Constitutional Commission, Final Report of the Constitutional Commission (1988) vol $1,[4.145]$.

Note 23. McGinty 212-13.

Note 24. Ibid 222.

Note 25. Ibid 221.

Note 26. In Australian Capital Television Pty Ltd v Commonwealth (No 2) (1992) 177 CLR 106 and Nationwide News Pty Ltd $v$ Wills (1992) 177 CLR 1. It should however be noted that although these cases mark the start of a line of decisions in which the proportionality test has been developed, the test has its origins in Adelaide Company of Jehovah's Witnesses v Commonwealth (1943) 67 CLR 116 where Starke J held (at 155) that limitations on the s 116 freedom of religion would be valid only if they were 'reasonably necessary for the protection of the community and the interests of social order'.

Note 27. Roach at 173-5.

Note 28. Ibid182.

Note 29. Ibid 186-8.

Note 30. Ibid 197.

Note 31. Ibid 199.

Note 32. Ibid 202.

Note 33. Ibid 12.

Note 34. Ibid 18-19.

Note 35. Ibid 19-20.

Note 36. Ibid 20-1.

Note 37. Ibid 38-9.

Note 38. Ibid 48.

Note 39. Ibid 49

Note 40. Ibid 51-2.

Note 41. Ibid 59. 
Note 42. Ibid 61-2.

Note 43. Ibid 326.

Note 44. Roach, 198.

Note 45. Rowe, 120-1.

Note 46. Ibid.

Note 47. In McKinlay see dicta at 39 (McTiernan and Jacobs JJ), 57 (Stephen J), 61 (Mason J) and 71-7 (Murphy $\mathrm{J}$ in dissent). In McGinty see 189 (Dawson J, who adopted the dictum by McTiernan and Jacobs JJ in McKinlay), 286 (Gummow J), 201 (Toohey J, in dissent) and 220-2 (Gaudron J in dissent).

Note 48. Roach, 199 (Gummow, Crennan and Kirby JJ).

Note 49. Rowe, 12, 20-1 (French CJ).

Note 50. The Commonwealth Constitution protects only five express rights: to just terms compensation for the acquisition of property (s 51(xxxi)), to jury trial in the case of indictable Commonwealth offences (s 80 ), to freedom of inter-State trade, commerce and intercourse (s 92), to religion (s 116) and to non-discrimination on grounds of residence in another State (s 117).

Note 51. Moore 327-9.

Note 52. At 136-40.

Note 53. At [110]- [111].

Note 54. See for example Anne Twomey 'The Federal Constitutional Right to Vote in Australia' (2000) 28 Federal Law Review 125; Anthony Gray 'The Guaranteed Right to Vote in Australia' (2007) 7 Queensland University of Technology Law and Justice Journal 178; George Williams 'Sounding the Core of Representative Democracy: Implied Freedoms and Electoral Reform' (1996) 20 Melbourne University Law Review 828; Bryan Mercurio and George Williams 'Australian Electoral Law: 'Free and Fair'?' (2004) 32 Federal Law Review 365. What is perhaps particularly astounding is that there was only one paper in the entire issue of the Federal Law Review devoted to electoral law (Volume 32(3), 2004) which discussed proportional representation - and the topic of that was the law in New Zealand. The disparities produced by the system in Australia went without comment.

Note 55. Rowe, 12.

Note 56. For an overview of democracy in ancient Athens see Mogan Hansen, The Athenian Democracy in the Age of Demosthenes (Blackwell, 1991) 90-3, 129.

Note 57. An example of such a system is that used under Article 4 of the Basic Law 1958 (Israel).

Note 58. Macquarie Dictionary, (Pan Macmillan Australia, $6^{\text {th }}$ ed, 2013) 421.

Note 59. For a survey of Australian electoral systems see Scott Bennett and Rob Lundie, 'Australian Electoral Systems' (Research Paper No 5, Parliamentary Library, Parliament of Australia, 2007).

Note 60. For an analysis of the proportionality of various voting systems see David Farrell and Ian McAllister, Voter Satisfaction and Electoral Systems: Does Preferential Voting in Candidate-Centred Systems make a Difference?(2004) Center for the Study of Democracy, UC Irvine .

$<\mathrm{http} / / / \mathrm{www}$.escholarship.org/uc/item/4c51z9mt?display=all\#page-10 > and H Catt, P Harris and N Roberts, Voter's Choice: Electoral Change in New Zealand? (Dunmore Press, 1992).

Note 61. See the discussion in David Farrell, Electoral Systems, A Comparative Introduction (Prentice Hall, 1997) ch 7.

Note 62. Information on elections in Ireland is obtainable from the Department of Environment, Community and Local Government at $<\mathrm{http}: / / \mathrm{www}$.environ.ie/en/LocalGovernment/Voting/>. A convenient summary of election results since 1918 can be found at Nicholas Whyte, Dail Elections (3 June 2007) $<$ http://www.ark.ac.uk/elections/gdala.htm>.

Note 63. In 1965 and 1969.

Note 64. In 1921, 1927, 1981, 1987, 1996 and 2008.

Note 65. See the discussion of Maltese election results at $<$ http://www.um.edu.mt/projects/maltaelections/elections/parliamentary $>$. 
Note 66. Information on elections in Tasmania can be obtained from the Tasmanian Electoral Commission at $<$ http://www.tec.tas.gov.au/> (accessed 10 October 2015). A summary of Tasmanian election results since 1909 can be found at Parliament of Tasmania, House of Assembly Election Results 1909-2014 (3 April 2014) $<$ http://www.parliament.tas.gov.au/tpl/Elections/ahares.htm> .

Note 67. In 1982 and 1989.

Note 68. Odd numbers of seats in electorates minimise the chances of results ending up with ties in the allocation of votes to candidates - see the discussion at <http://aceproject.org/ace-en/topics/es/esd/esd02/default $>$.

\section{Copyrights}

Copyright for this article is retained by the author(s), with first publication rights granted to the journal.

This is an open-access article distributed under the terms and conditions of the Creative Commons Attribution license (http://creativecommons.org/licenses/by/3.0/). 